\title{
Research on the Mode of Science and Technology Achievements Transformation in Chinese Universities - Shanghai University of Engineering Science
}

\author{
Na Deng ${ }^{1}$, Miaojun Dong ${ }^{2} \&$ Haosi Chen ${ }^{1}$ \\ ${ }^{1}$ Shanghai University of Engineering Science, Shanghai, China \\ ${ }^{2}$ Shanghai Education Committee Science and Technology Development Center, Shanghai, China \\ Correspondence: Na Deng, Longteng Road 333, Songjiang District, Shanghai, China. E-mail: dn918@163.com
}

Received: June 12, 2014

Accepted: June 26, 2014

Online Published: August 10, 2014

doi:10.5430/jms.v5n3p10

URL: http://dx.doi.org/10.5430/jms.v5n3p10

\begin{abstract}
Science and technology achievements transformation's work in China universities faces new development opportunities and challenges. Based on Shanghai University of Engineering Science as an example, this paper studies local university of science and technology achievements transformation mode. Discussed respectively by means of social organization, technology exchange, Shanghai municipal education commission science and technology development center, district science and technology commission, the national university science park, to carry out the transformation of scientific and technological achievements, promote the university science and technology achievement transformation measures, to promote to social transformation and industrialization of scientific and technological achievements, serve the society economic development.
\end{abstract}

Keywords: university, science and technology achievements transformation, mode

\section{The Definition of Science and Technology Achievements Transformation}

In this article science and technology achievements transformation refers to the scientific research and technology development of practical science and technology achievements of follow-up tests, development, application and promotion until the formation of new products, new technology, new materials, development of new industries and other activities.

2. Analysis on Mode of Science and Technology Achievements Transformation - Shanghai University of Engineering Science

2.1 Mode One: With the Help of a Social Group - Science and Technology Achievements Transformation of Shanghai Association for the Advancement of Building the Platform

2.1.1 Alliance Plan - A Problem the Bidding Projects

Council for the association of promoting science and technology transformation of shanghai launch plans, is through to the collection of small and medium-sized enterprises in Shanghai is put forward in the process of development of the technical problems and public bidding, the organizations in colleges and universities and scientific research institutes and other units to use existing technology or JieBiao, one-to-many condition, be determined by the independent corporate partners, to help small and medium-sized enterprises to solve problems through the industry-university-institute cooperation. For docking success and through the review of project, promote the funding will be given (shown in figure 1). This kind of mode is the feature of "industry-university-institute" cooperation: cycle short, quick effect, has funded, is well received in the enterprises and colleges and universities. Since this project has been nine years, has a good reputation in society. Need to pay attention to the problem is the balanced distribution of resources, put forward several problems for a enterprise, and a project team to undertake multiple projects should be limited. 


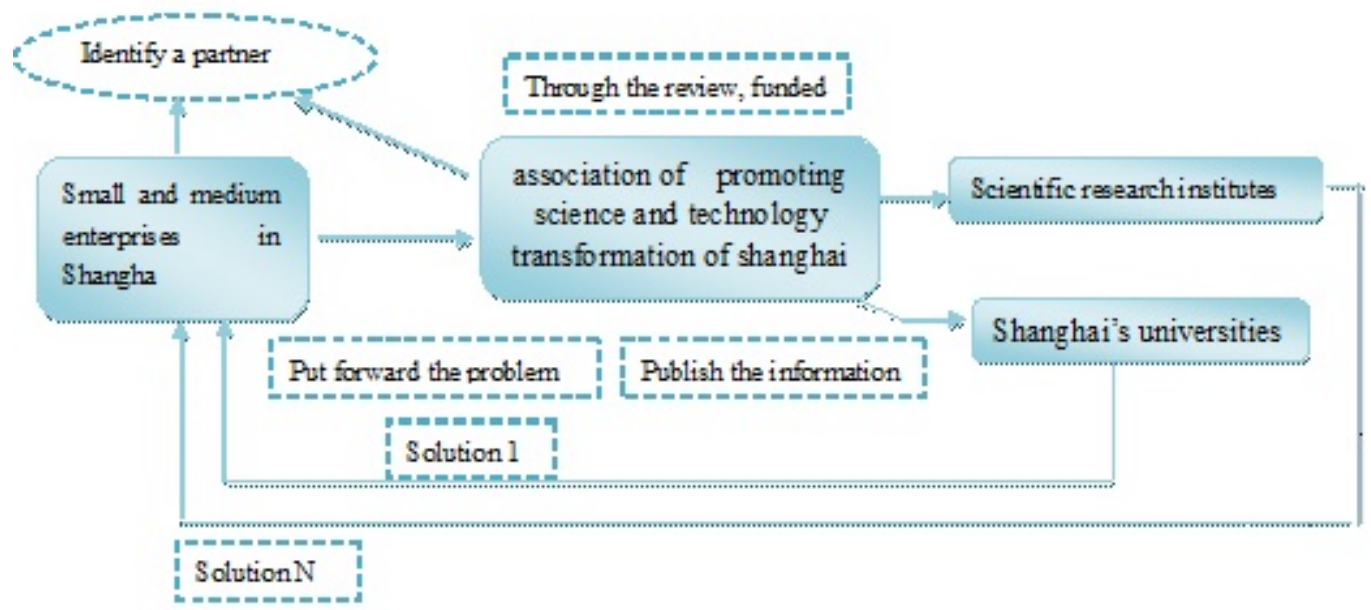

Figure 1

\subsubsection{Booster Plan - Special Achievements Transformation of Colleges and Universities}

Booster plan is a common concern and support of Shanghai people's political consultative conference and the Shanghai municipal education commission project, the Shanghai municipal council for the promotion of science and technology achievements transformation (hereinafter referred to as division will promote) and science development center jointly organize their implementation. For independent research and development, with independent intellectual property rights in Shanghai universities scientific research project, technical procurement of enterprise, so as to promote the transfer of scientific and technological achievements, help enterprise technology upgrading and transformation of development. First carries on the collection of technical achievements, selection sort, expert evaluation, determine the booster program transformation project in colleges and universities; Through to the enterprise project information platform and organizational activities, and advance demand information communication project in colleges and universities and enterprises, university-enterprise cooperation projects, cooperation contract talks, signed a technology transfer contract for achievements project, education funding of colleges and universities, families, and promote will be funded enterprises (Figure 6). Such achievements transformation model is increased by selecting assessment link according to the characteristics of the project is more promotion value, get funding for colleges and universities and enterprises, to improve the enthusiasm of achievements, because of the prophase research, fully project design more reasonable, practice and exploration.

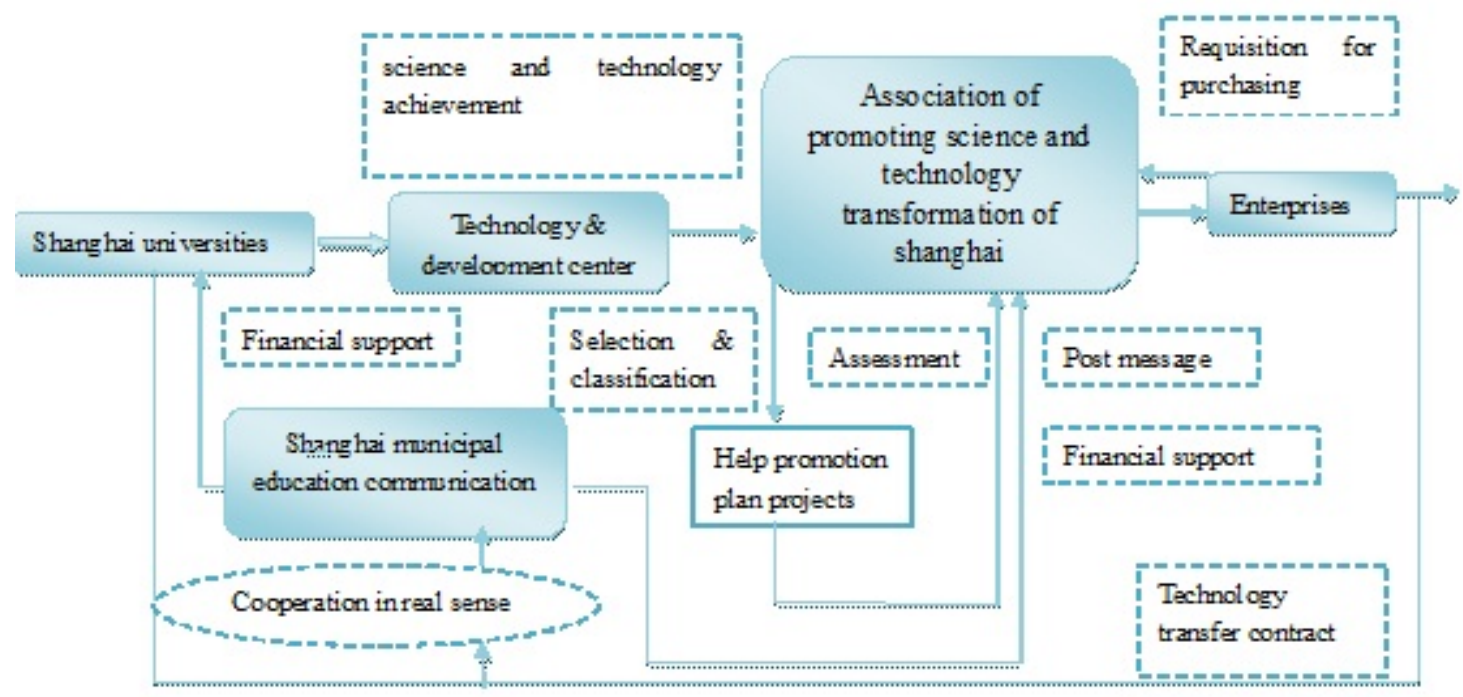

Figure 2 


\subsection{Mode 2: Use Shanghai Technology Transfer \& Exchange's Platforms}

Shanghai technology transfer \& exchange will not regularly send the enterprise technical requirements to colleges and universities, scientific bureau organize teachers to participate in the project docking, facilitate the science and technology achievements transformation and technology transfer.

\subsection{Mode 3: Use Shanghai Education Science Service Center's Platform}

Shanghai Education Science Service Center (referred to as SHESC) is the Shanghai City Board of education directly affiliated institutions, and promotes the development of undertaking to guide and coordinate the work of the city's university technology transfer, research cooperation and technology industry. The center in the Yangtze River Delta region and promote research work has established close cooperative relations of long-term, and gradually expand to Guangdong, Fujian, Shandong etc.

\subsubsection{Project Collection- Document Assembly- Establish Contact- Reach Collaboration}

The school actively collects the latest scientific and technological achievements, the science center, published this year "Shanghai university technology transfer promotion project assembly", issued to the cooperation of enterprises. Enterprises are interested in seeing the project, take the initiative to contact the college, promote cooperation between the two sides (Shown in Figure 3). The signing of the 2011 Shanghai University of Engineering Science and Zhejiang Yahe Textile Company Limited on the high performance of emulsion paint technology key basic research project is the successful docking. This result is transformed path: the project is complete, good timeliness, ease of business contact University, but the university more passive, can only wait for the enterprises to know nothing at all, to the enterprise information.

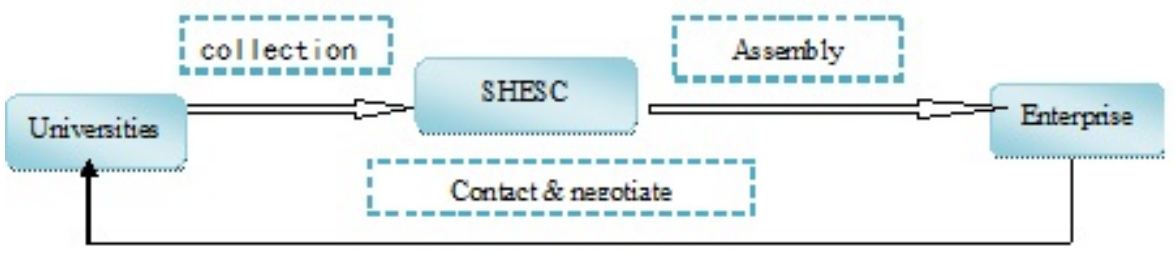

Figure 3

2.3.2 Organizations with the SHESC, Take Part in All Kinds of Scientific and Technological Achievements Exhibition and Cooperation Fair

SHESC contacts with the local bureau of science and technology closely. Through the "going out" and "coming in" form, the organization to participate in various kinds of scientific and technological achievements exhibition and cooperation fair. The school organizes the project and expert, participated in the 2012 Xinghua autumn trade fair, the first 2012 Haimen Science Festival, the fourth (Shanghai) International Disaster Reduction and safety fairs. To carry out such research activities, SHESC in the early to do a good job of liaison and communication with the local science and Technology Bureau, according to the regional characteristics and industrial structure, the targeted for project selection, the panel or face to face communication and business personnel, reached a preliminary cooperation intention, to lay the foundation for the work of the next step (Figure 4). The characteristics of transformation path of such achievement is: according to the industrial layout selection project, targeted to a certain extent, experts and technical personnel to communicate with each other face to face exchanges, build mutual trust. Because it is local government organizations, some enterprises in order to complete the task, the demand will not strong, attendance is not professional, the effect is not obvious.

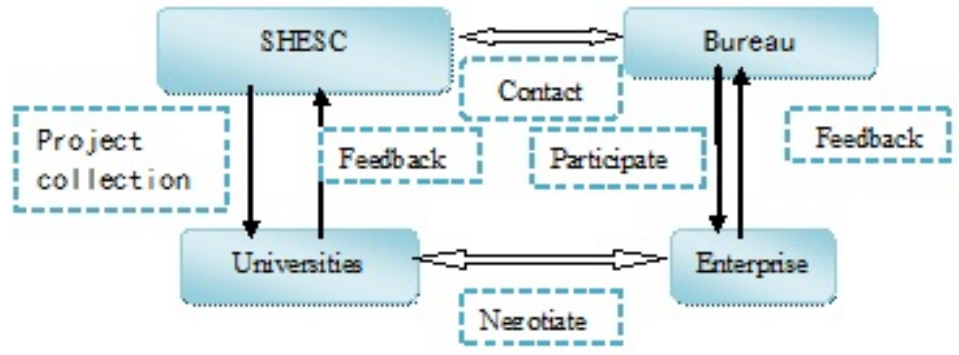

Figure 4 


\subsubsection{Shanghai Industrial Exposition and University Technology Market}

Chinese (Shanghai) International Industry Fair has become an important platform for universities to promote science and technology innovation achievements show and seek the innovation of science and technology achievements transformation and industrialization of opportunity. In order to encourage teachers to participate in the Expo, Shanghai University of Engineering Science college fund set up special Expo special, for the financing of the project team, in recent years the teachers actively participate in Expo improved obviously. In the careful organization of the school in the center, University Science and Technology Park, teachers and students innovative projects in selected high maturity of the project on behalf of the exhibitors, the exhibition booths, promotion, organization of Technical Brokers field and enterprises to discuss cooperation, participate in the forum, Reporting Awards, signing such links, actively participate in related work Expo in. Science and technology development center in addition to contact all over the Bureau of science and technology, do a good job in the organization and reception work, but also to create not ending of the Expo, making full use of exhibition resources, extension of technology innovation show effect, for screening project into the Shanghai University of technology markets, perennial display (Figure 5. The Expo as a carrier to develop technology to promote economic exchanges will provide an impetus to cooperation and enterprise independent innovation platform. Basically industrial automation industry exhibition in the international first-class level, machine tool exhibition in the domestic first-class level, local universities should not only in the pavilion as exhibitors have a space for one person, should use this platform to study, to communicate, to broaden our horizons, as college teachers professional audiences, active participation needs to be further improved.

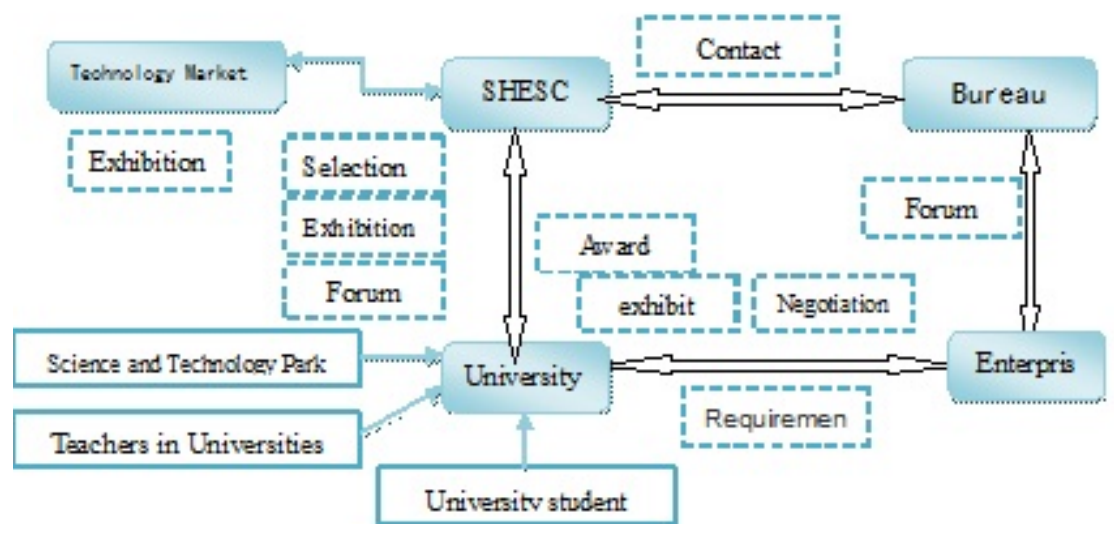

Figure 5

\subsubsection{Docking of Shanghai Universities and Small-Medium Enterprises}

According to the Ministry of education and Shanghai Economic and Information Technology Commission about structures and efficient services to small and medium enterprises cooperation spirit, center development services to small and medium enterprises technology center and Shanghai signed a "strategic industry cooperation agreement", the spirit of "complementary advantages, mutual benefit and cooperation, pay attention to actual effect, common development" principle, to carry out comprehensive cooperation in release of information, technology and service, personnel exchanges and cooperation. A center contact University Development Service Center, Shanghai small and medium-sized enterprise with enterprises, joint research and joint activities. Enterprises demand information collected by the center for the development of services for small and medium-sized enterprises in Shanghai City, the Branch Center issued to colleges and universities, colleges and universities to undertake the project information and feedback to the branch center, teachers and enterprise organization docking, contributed to the project cooperation. For substantive cooperation of colleges and universities, education grants (Figure 6). The characteristics of the technology achievements transformation is: the workload is bigger, the docking process, the success rate is relatively high. With funding, and more to enhance the enthusiasm of university. Areas in need of improvement are: small and medium-sized enterprises to describe the technology needs to be further standardized; butt if in accordance with industry organizations, will be more effective to build information platform, improve efficiency. 


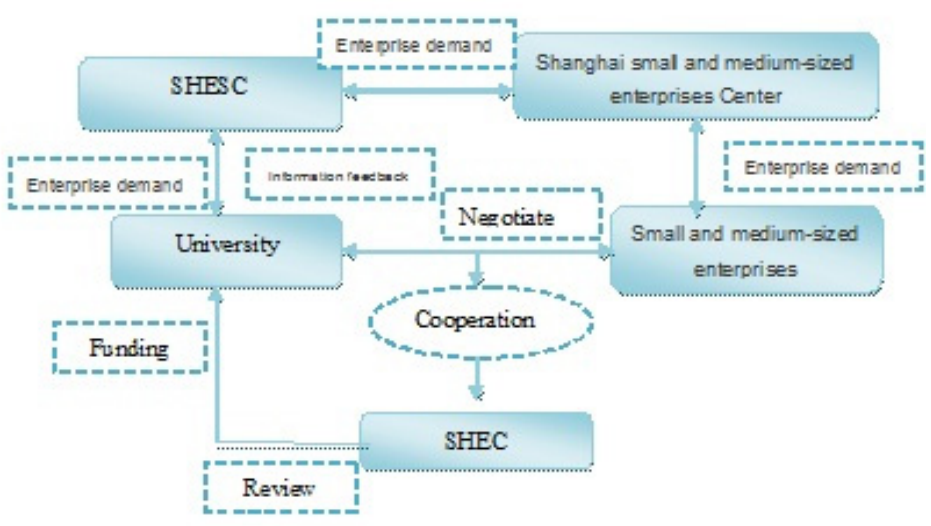

Figure 6

2.4 Mode 4: Contact Closely with the District Science and Technology Commission, Promoting the Transformation of Technological Achievements

Together with SongJiang science and technology commission, SongJiang tissue engineers association activities related to recommend multiple, professor at the school served as professional committee, director of the school actively in SongJiang, and to strengthen the communication with songjiang enterprises industry-university-institute cooperation to build a new platform. And BaoShan district production, science and technology commission office has the good communication and cooperation, the production, the office of BaoShan district according to the school and enterprise cooperation take out money to the university. With preparation declare science and technology commission of Shanghai ChangNing district government cooperation "district hot plan" project.

2.5 Mode 5: Cooperating with the National University Science and Technology Park Promote the Science and Technology Achievements Transformation

Promote the staff engaged in science and technology achievements transformation in national university science and technology park, implementing the policy to promote knowledge service development of a new platform. With the national university science park joint declaration of ZhangJiang special "smart TV industry cluster". To participate in the national university science park LuoYang production-study-research cooperation fields.

\subsection{Mode 6: Teachers Contact Companies Directly to the Science and Technology Achievements Transformation}

Teachers on the basis of the original cooperation or make contact with the enterprise itself, through 4 type contract (technology development, technical services, technical consulting, technology transfer), the realization of technology transfer and science and technology achievements transformation. This kind of cooperation method is common, in local colleges and universities majority.

\section{Understanding of the Working of Science and Technology Achievements Transformation}

Science and technology achievements transformation is in the middle of the science and technology chain, connected with the science and technology innovation source and the development of science and technology industry. So the technology transfer success or failure, it will directly affect the development of science and technology, working in the industry. But the importance of technology transfer, and not just in the technology itself, should proceed from the overall development of the national economy. Its background is to rely on a lot of use of resources, damage the environment, development rely on cheap labor must depend on scientific and technological progress, rely on independent innovation, rely on improving the labor quality of the track. On the one hand is the enterprise competition, industrial upgrading, regional economic development and national economic construction need technical support a large, is a university and Research Institute, large number of scientific and technological achievements put it away unheeded, cannot be transformed into productivity. To speed up scientific and technological survival transformation and technology transfer, it is an important way to realize the combination of technology and economy.

\section{The Advice and Countermeasures to Science and Technology Achievements Transformation}

4.1 Department of scientific research, local university technology transfer center, Science Park, straightening out relations, promote mutual promoting force, the formation of university technology transfer and science and technology achievements transformation, achieve complementary advantages.

4.2 In the evaluation of professional titles, varying only the project, evaluation mechanism, award for multi-directional multi-level, introducing the technology transfer title of Professor series, let the project do good 
teachers can also have the title promotion opportunities.

4.3 Develop technical broker role, become disorderly spontaneous action organized to carry out technical management. If the school to two college of technology brokers to the number and amount of items as evaluation index has played a positive role; education branch center organization technology brokers training is helpful to improve the technical broker business ability and quality, to strengthen the support, from the project and funding support, the necessary to study and further studies.

4.4 Board of Education should be the integration of Shanghai university resources, encourage the school to carry out joint technology development and Research on science and technology, more competitive relationship between the schools, the spontaneous formation of university school cooperation is relatively difficult. As in the assessment of school when the school to carry out joint cooperation to increase coefficient. For the repeated construction of disciplines and professional, appropriate to takeout system.

4.5 Science and technology service organizations or institutions of technology transfer cooperation, complementary advantages, such as: SHESC play the close ties between Shanghai and the Yangtze River Delta in bureau of science and technology advantage; AAAs will play the connections and talent advantage; scientific research management department in Colleges and universities play a familiar with the school science and technology achievements advantage; technology exchange play to become familiar with the technology advantages of market rules, form resultant force, play advantage for the organization, university technology transfer and science and technology achievements transformation to clear the path.

\section{The Local Policy}

To promote technology transfer and transformation of scientific and technological achievements, active and prosperity of this municipality's technology market, and promote the development of small and medium-sized enterprises innovation, Shanghai science and technology commission and Shanghai municipal finance bureau jointly issued the "measures for the implementation of technology brokerage in Shanghai to promote the development of " file. For mobilizing the enthusiasm and creativity of science and technology personnel in colleges and universities, promote the innovation and transformation of scientific and technological achievements of scientific and technological achievements, promote knowledge service function of colleges and universities, promote the discipline construction in colleges and universities, Shanghai municipal education commission issued the Shanghai education committee system of higher school science and technology achievements transformation and its implementing rules for the equity incentive provisional. Shanghai municipal education commission launched the project of Shanghai university knowledge service ability to ascend. Engineering around Shanghai and the national economic and social development needs, to carry out the key industries in the field of core technology research and development, the research on theory and practice questions of social development, establish and improve the cooperative innovation mechanism.

\section{Conclusion}

In recent years, China's implementation of the development strategy of innovation oriented country, and proposed to establish a "take the enterprise as the main body, the market as the guidance, combining the research of" science and technology innovation system. Local colleges and universities in the national innovation strategy under the guidance of active use of regional advantages, school location, explore the new mode of technology transfer and science and technology achievements transformation, strengthening cooperation and innovation consciousness, improve collaborative innovation environment, build collaborative innovation platform, establish cooperative innovation alliance, seize the opportunity, change the challenge into power, and make greater contribution to as the regional economic and social development.

\section{References}

H. Liu, \& Y.Zhou. (2012). The Technology Transfer Policy System and Its Coordination Mechanism Research. Scientific Research Management, 33(3), 105-111.

Ines, Macho-Stadler, \& David, Perez-Castrillo. (2010). Incentives in University Technology Transfers. Inernational Journal of Industrial Organization, (28), 362-367.

S. Y. Wu. (Ed.). (2007). Intangible Assets Management and Evaluation. The Capital Economic and Trade University Publishers, Beijing.

W. Xue, \& S.J.Wei. (2013). The Main Problems and Recommendations of Tax Policy for Stock Incentive in China. Science and Technology of China BBS, (1), 30-36.

Y. C. Zhang. (Ed.). (2009). Study on Mechanism of Technology Transfer. China Economic Publishing House Publishers, Beijing. 